\title{
DESIGN AND DEVELOPMENT OF PNEUMATIC COTTON BOLL PICKING MACHINE
}

\section{N. G. MAHALLE ${ }^{1}$, P. M. SIRSAT ${ }^{2}$, S. V. SONTAKKE ${ }^{3}$, WASHIMRAJA SHEIKH ${ }^{4}$ \& S. A.WELEKAR ${ }^{5}$ \\ ${ }_{1,2,3,4}$ Assistant Professor, Mechanical Engineering Department, Priyadarshini College of Engineering,}

Nagpur, Maharashtra, India

${ }^{5}$ Assistant Professor, Mechanical Engineering Department, Priyadarshini Institute of Engineering \&

Technology, Nagpur, Maharashtra, India

\begin{abstract}
This paper focuses on design and development of a new machine, to pick cotton bolls. In India, entire cotton is handpicked by labour, and internationally available machines for picking the cotton bolls are costlier and not affordable to Indian farmers. Also, these machines are not suitable for Indian farming condition. Pneumatic cotton boll picking machine, will give a new technology in the field of agriculture which is helpful for Indian farmers.

KEY WORDS: Cotton Boll Picking Machine, CFD Analysis, Impeller \& Tetrahedron Elements
\end{abstract}

Received: Aug 19, 2017; Accepted: Sep 08, 2017; Published: Sep 16, 2017; Paper Id.: IJMPERDOCT201721

\section{INTRODUCTION}

In the world, China and India are the largest producers of cotton. Cotton is an important commercial crop in India. In India, the state of Maharashtra, Gujarat, Andhra Pradesh and Madhya Pradesh are lading cotton producing states, where cotton is harvested manually. A cotton boll picking machine, that plucks the cotton from the boll without damaging the cotton plants, does not exist in India. The average land holding capacity of farmers is 1-3 hectares of land. Hence, pneumatic cotton-picking machine will be very useful for Indian farmers, for minimizing drudgery involving in hand picking.

A pneumatic type cotton boll picking machine has been designed and developed, to pluck cotton from cotton boll, by using pure suction method. When engine gets started, impeller starts rotating and suction is created at the outlet. By using this suction pressure, cotton can be picked from cotton boll, with the help of hose pipe. Pneumatic cotton boll picking machine, has been designed ergonomically, having low weight and very efficient for Indian farms. It is a knapsack type machine. The proposed machine is affordable and easy to handle. Farmers can easily use pneumatic cotton-picking machine, without fatigue. 


\section{Main Components}

Table 1: Main Components

\begin{tabular}{|c|c|c|c|c|}
\hline $\begin{array}{c}\text { Name of } \\
\text { Component }\end{array}$ & Figure & Dimension & Material & Weight \\
\hline Frame & & $10 \mathrm{~mm}$ diameter & Mild Steel & $2.2 \mathrm{Kg}$ \\
\hline Tank & & $\begin{array}{l}600 \mathrm{~mm} \text { length } \\
\text { and } \\
150 \mathrm{~mm} \text { diameter }\end{array}$ & Plastic & $0.8 \mathrm{~kg}$ \\
\hline Impeller & & $\begin{array}{l}\text { Inner diameter } 70 \mathrm{~mm} \\
\text { Outer diameter } \\
240 \mathrm{~mm} \text {. }\end{array}$ & $\begin{array}{l}\text { Fiber casing with } \\
\text { steel blade. }\end{array}$ & $1.8 \mathrm{~kg}$ \\
\hline $\begin{array}{l}\text { Two Stroke IC } \\
\text { Engine }\end{array}$ & & $\begin{array}{l}\text { Rallis L-35/HPO } \\
\text { Bore- } 35 \mathrm{~mm} \\
\text { Stroke-36mm } \\
\mathrm{P}=1.34 \mathrm{KW}\end{array}$ & & $4.2 \mathrm{Kg}$ \\
\hline Spark Plug & & Mico W17521Type & & $0.1 \mathrm{Kg}$ \\
\hline Pipe & & $\begin{array}{l}30 * 300 \mathrm{~mm} \text { and } 50 * \\
1000 \mathrm{~mm} \text { (Diameter } \times \\
\text { length) }\end{array}$ & & $0.1 \mathrm{~kg}$ \\
\hline \multicolumn{4}{|c|}{ Total Weight of Machine } & $9.2 \mathrm{~kg}$ \\
\hline
\end{tabular}

\section{DESIGN CALCULATIONS}

The pneumatic force required to pluck a normal cotton boll is $3.5 \mathrm{~N}$, with discharge of $0.025 \mathrm{~m}^{3} / \mathrm{s}$ (velocity $=12.73$ $\mathrm{m} / \mathrm{s}$ ). A standard $1.34 \mathrm{KW}$ powered two strokes IC- Engine, with $500 \mathrm{rpm}$ has been used, which have been connected with impeller to produce the required force, to pluck cotton boll from cotton.

\section{Design of Shaft $\left(\mathbf{D}_{\mathrm{s}}\right)$}


Motor Power $=\mathrm{P}=1.34 \mathrm{KW}$.

Speed $=\mathrm{N}=500$ r.p.m.

Power $P=\frac{2 \pi N T}{60} \times \mathrm{K}_{\mathrm{L}}$

Where, $\mathrm{K}_{\mathrm{L}}$-Load factor $=1.15 ; \mathrm{T}$-Torque

$\mathrm{T}=19.606 \mathrm{~N}-\mathrm{m}$

Considering material SAE 1030 and factor of safety is 3 .

Permissible shear stress $=\tau=61 \mathrm{~N} / \mathrm{mm}^{2}$

$\mathrm{T}=\frac{\pi}{16} \tau \mathrm{D}_{\mathrm{s}}^{3}$

$\mathrm{D}_{\mathrm{s}}=11.78 \mathrm{~mm}$

Increasing the diameter by $50 \%$

$\mathrm{D}_{\mathrm{s}}=17.67 \mathrm{~mm}$.

Standardizing diameter of Shaft $=20 \mathrm{~mm}[7]$

\section{Design of Impeller}

The diameter of the impeller eye, $D_{0}$, depends on the shaft diameter, $D_{s}$. The hub diameter, $D_{H}$, is made $5 / 16$ to $1 / 2$ inch larger than $D_{s}$. After estimating $D_{s}$ and $D_{H}, D_{0}$ is based on the known flow rate. To ensure smooth flow, the inlet vane diameter $D_{1}$, has made about the same as $D_{0}$. $D_{2}$ is outlet vane diameter.

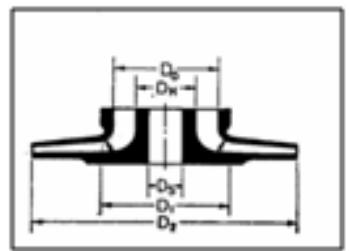

Figure 1: Cross Section of Impeller

$\mathrm{D}_{\mathrm{H}}=\frac{5}{16} \quad \mathrm{D}_{\mathrm{s}}+\mathrm{D}_{\mathrm{s}}$

$\mathrm{D}_{\mathrm{H}}=\frac{5}{16} 20+20$

$\mathrm{D}_{\mathrm{H}}=26.25 \mathrm{~mm}$

Considering hub diameter $=28 \mathrm{~mm}$.

Selected impeller discharge is $0.04 \mathrm{~m}^{3} / \mathrm{s}$, and the required discharge is $0.25 \mathrm{~m}^{3} / \mathrm{s}$, with velocity of $12.73 \mathrm{~m} / \mathrm{s}$.

$\mathrm{V}_{\mathrm{su}}=\mathrm{V}_{\mathrm{o}}=12.73 \mathrm{~m} / \mathrm{s}$

$\mathrm{Q}=\mathrm{V}_{\mathrm{su}} \mathrm{D}_{\mathrm{s}} \mathrm{u}^{2} / 4$

$\mathrm{D}_{\mathrm{s}} \mathrm{u}^{2}=50 \mathrm{~mm}$ 
Since, required suction pipe diameter is $50 \mathrm{~mm}$.

$\mathrm{Q}=\mathrm{V}_{\mathrm{o}}\left(\frac{\pi D 02}{4}-\frac{\pi \mathrm{DH} 2}{4}\right)$

$\mathrm{D}_{\mathrm{o}}=68.49 \mathrm{~mm}=\mathrm{D}_{1}$

Since inlet diameter of impeller is 70mm (Standard Diameter).[7]

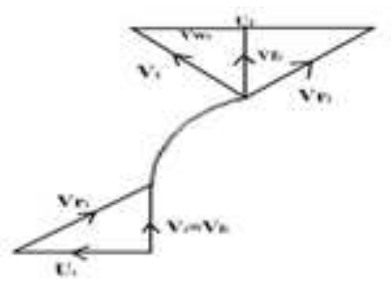

Figure 2: Velocity Diagram

$\mathrm{U}_{1}=\frac{\pi D 1 N}{60}$

$\mathrm{U}_{1}=\frac{3.14 * 70 * 500}{60 * 1000}$

$\mathrm{U}_{1}=18.32 \mathrm{~m} / \mathrm{s}$

Inlet angle is usually $10^{\circ}-25^{\circ}$.

As per the impeller vane blade, inlet angle $\theta$ is

$\theta=13^{\circ}$ (vane angle at inlet)

$\tan \theta=\frac{V f 1}{U 1}$

$V_{f 1}=18.80 \mathrm{~m} / \mathrm{s}$

Width of the Impeller,

$\mathrm{b}_{1}=\frac{Q}{\pi \varepsilon f f 1 D 1}$

Where $\varepsilon^{\prime}=0.85$

$\mathrm{b}_{1}=50.62 \mathrm{~mm}$

From inlet velocity triangle

$\mathrm{V}_{\mathrm{r} 1}=18.80 \mathrm{~m} / \mathrm{s}$

Outlet Diameter of Impeller is $240 \mathrm{~mm}$

$\mathrm{U}_{2}=\frac{\pi D 2 N}{60}$

$\mathrm{U}_{2}=62.8 \mathrm{~m} / \mathrm{s}$

The normal range of discharge angle is $20^{\circ}-25^{\circ}$. 
$\varnothing=20^{\circ}$ (outlet angle of impeller).

$\mathrm{V}_{\mathrm{f} 1}-\mathrm{V}_{\mathrm{f} 2}=4.229 \mathrm{~m} / \mathrm{s}$.

$\tan \theta=\frac{V f 2}{U 2-V w 2}$

$\mathrm{V}_{\mathrm{w} 2}=51.18 \mathrm{~m} / \mathrm{s}$.

$\operatorname{Tan} \beta=\frac{V f 2}{V w 2}$

$\beta=4.72^{0}$

$\mathrm{V}_{\mathrm{r} 2}=\sqrt{\{(\mathrm{U} 2-\mathrm{Vw} 2) 2+V f 2\}}$

$\mathrm{V}_{\mathrm{r} 2}=12.36 \mathrm{~m} / \mathrm{s}$

\section{Pressure Calculation}

Pressure created by impeller at the outlet.

$\mathrm{P}=249.08 * 1.1\left(\frac{N * D * 39.37}{153 * 10^{4}}\right) \cdot 2$

$\mathrm{P}=2612.41 \mathrm{~Pa}$.

Now,

$\mathrm{P}=\rho g \mathrm{H}$

Where,

$\mathrm{H}=225.10 \mathrm{~m}$

$V=\sqrt{2 \times 9.81 \times H}$

$\mathrm{V}=66.45 \mathrm{~m} / \mathrm{s}$

Velocity at the outlet of impeller is $66.45 \mathrm{~m} / \mathrm{s}$.

Pressure difference,

$\Delta \mathrm{P}=\mathrm{P}_{2}-\mathrm{P}_{1}$

$\Delta \mathrm{P}=-98732.59 \mathrm{~N} / \mathrm{m}^{2}$

Pressure Ratio $=\mathrm{P}_{2} / \mathrm{P}_{1}$

$=0.025577$.

This pressure difference is sufficient to pluck cotton from cotton boll.

\section{Hose Pipe Design}

Pipe diameter from impeller to the tank, $D_{\text {pipe }}$ :

$\mathrm{Q}=\mathrm{AV}$ 
$0.04=\frac{\pi}{4} \mathrm{D}_{\text {pipe }}^{2} \times 66.45$

$\mathrm{D}_{\text {pipe }}=29.37 \cong 30 \mathrm{~mm}$

Velocity inside the pipe

$\mathrm{Q}=\mathrm{AV}$

Where,

A-Cross-sectional area of pipe and V-velocity of flow through pipe

$0.04=\frac{\pi}{4} \mathrm{D}_{\text {pipe }}^{2} \mathrm{x} \mathrm{V}$

$\mathrm{V}=56.617 \mathrm{~m} / \mathrm{s}$.

Head loss due to friction

$\mathrm{H}_{1}=\frac{4 f L}{2 g \text { D pipe }} \mathrm{V}^{2}$

Where,

$f$-Coefficient of friction; L- Length of pipe; V-Velocity inside the pipe

$\operatorname{Re}=\frac{V D \text { pipe }}{v}$

Re - Renold's Number.

$v$ - Kinematic viscosity of air

$\operatorname{Re}=\frac{56.617 \times 0.3}{15.98 \times 10-6}$

$\operatorname{Re}=1.24579 \times 10^{5}$

Coefficient of friction

$f=\frac{0.0791}{R e 1 / 4}=0.004208$

$\mathrm{H}_{1}=\frac{4 \times 0.004208 \times 0.3 \times 56.6172}{2 \times 9.81 \times 0.03}=0.12$

Velocity of flow inside the tank.

$\mathrm{A}_{1} \mathrm{~V}_{1}=\mathrm{A}_{2} \mathrm{~V}_{2}$

$\mathrm{V}_{2}=2.26 \mathrm{~m} / \mathrm{s}$

Now,

Velocity at suction pipe

$\mathrm{A}_{2} \mathrm{~V}_{2}=\mathrm{A}_{3} \mathrm{~V}_{3}$

$\mathrm{V}_{3}=20.34 \mathrm{~m} / \mathrm{s}$ 
As required velocity is $12.73 \mathrm{~m} / \mathrm{s}$ and calculated velocity, at suction pipe outlet is $20.34 \mathrm{~m} / \mathrm{s}$. So, with the velocity available at suction pipe outlet, it is possible to pluck cotton from cotton boll.

\section{CFD ANALYSIS}

The CFD analysis has been carried out using Ansys13.Workbench Software. The process involved following steps

- Design of blade model as per input parameter.

- The model is meshed using tetrahedron elements of size $2 \mathrm{~mm}$. The mesh is fined at areas near to the blade thus, providing a fine boundary layer for simulation. The meshed domain is the fluid domain.

- Creating of the solver setup in which, the model of the fluid domain was divided into regions of inlet \& outlet surfaces.

- Determining parameters, that needed as input pressure, pressure ratio, density etc.

Using this procedure, CFD Analysis of impeller has been carried out, and velocity and pressure on blade has been calculated. There are 18 blades and flow system, that has been considered as an axial inlet and radial outlet type.

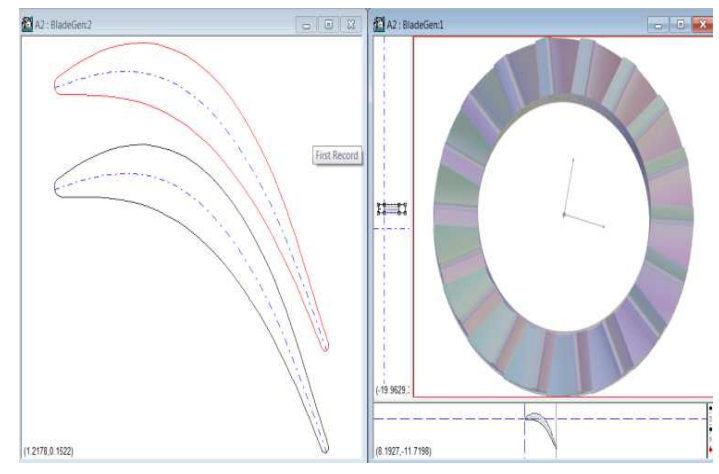

Figure 3: Blade Design

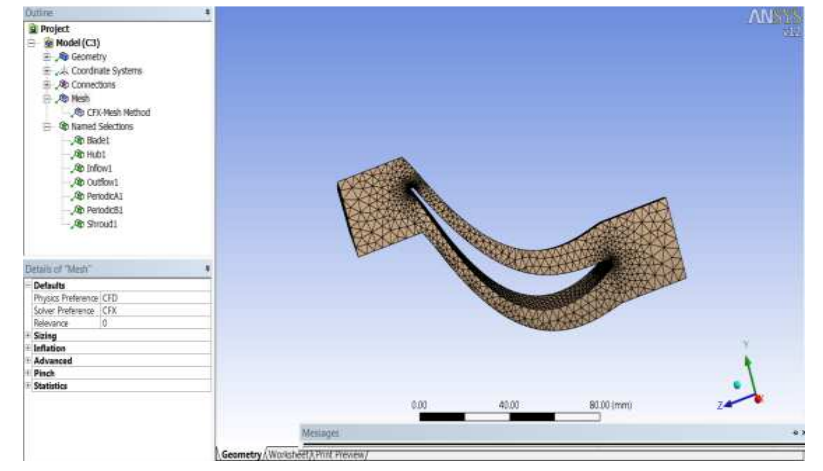

Figure 4: Meshing of Blade

Analysis was considered as Steady State Analysis. Fluid domain was considered as air with the given settings, as the above EPISELON turbulence model, used for turbulence modeling.

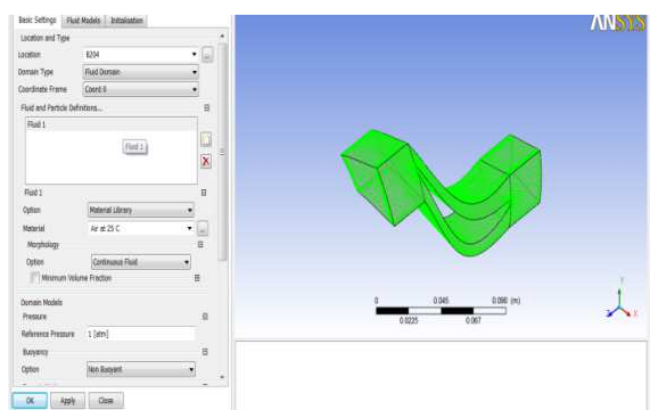

Figure 5: Flow of Fluid

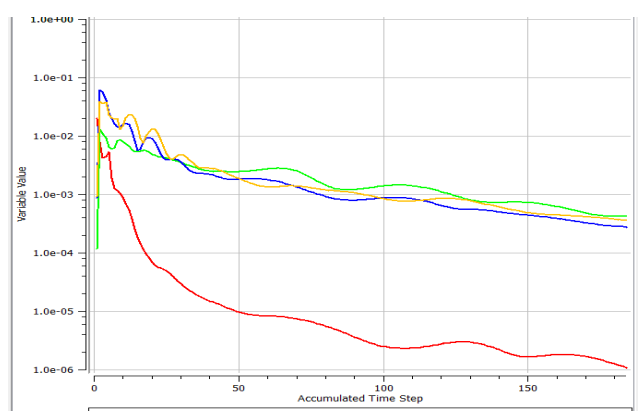

Figure 6: Iteration Graph

Convergence criteria have been considered as 0.001 , for both the pressure and velocity. The results are obtained by taking 190 iterations, till the model shows the required criteria that is needed. 


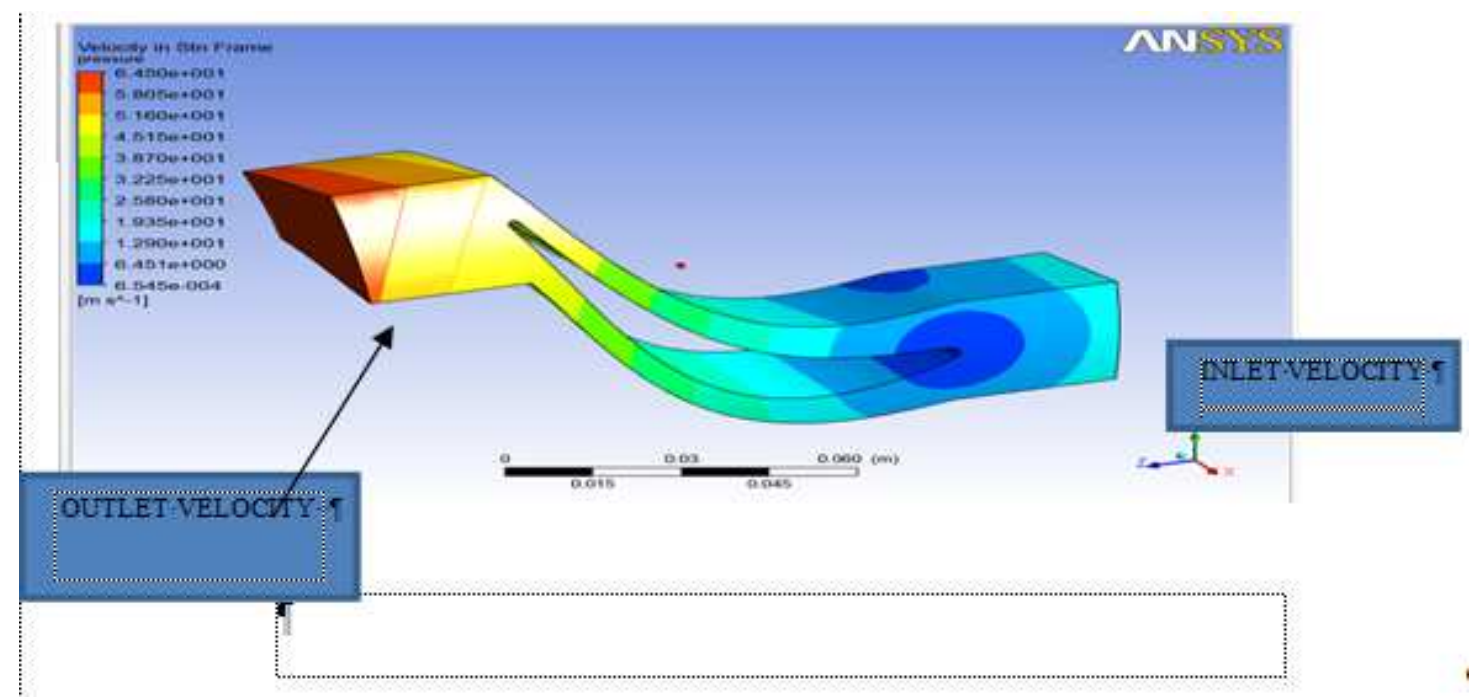

Figure 7: Stagnant Velocity at Inlet and Outlet

The velocity at the outlet was found to be $64.50 \mathrm{~m} / \mathrm{s}$.

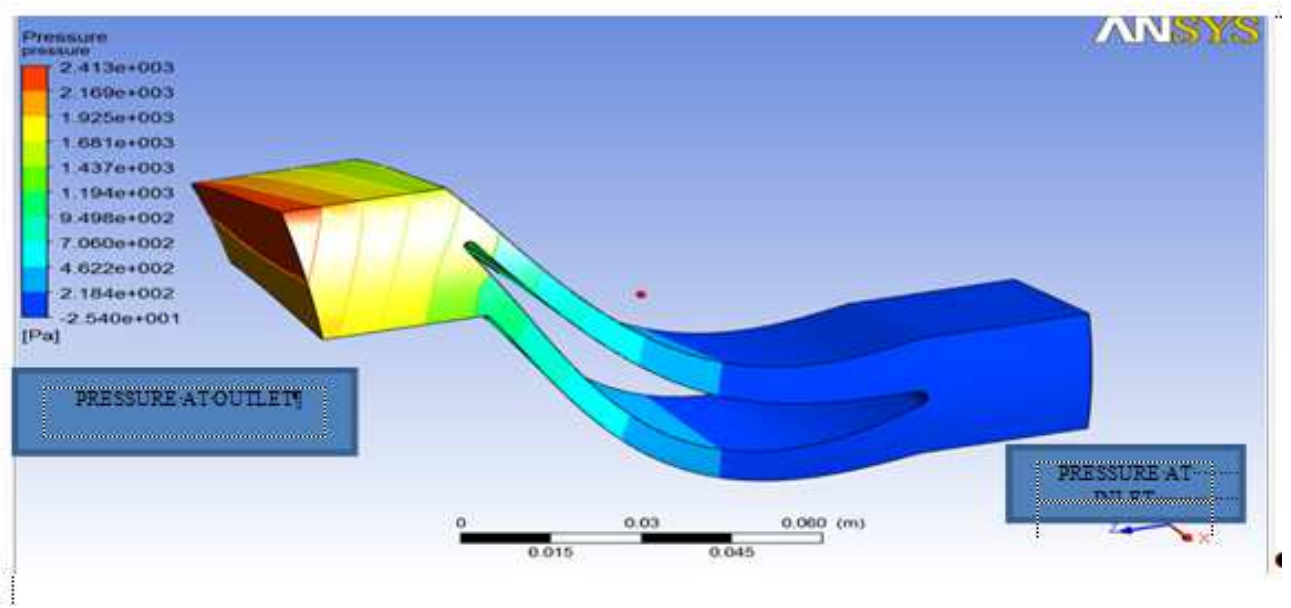

Figure 8: Pressure at Inlet and Outlet

The outlet pressure was found to be $2413 \mathrm{~Pa}$.

\section{MACHINE DRAWINGS}

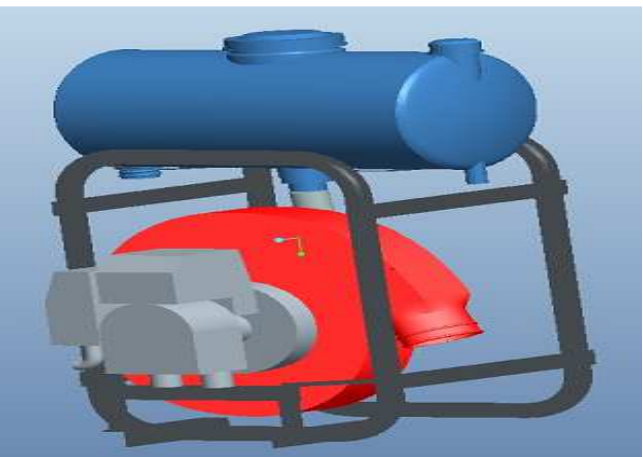

Figure 9: Cad Model

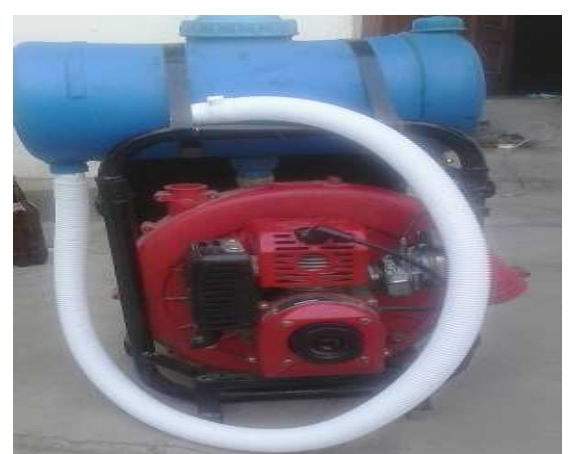

Figure 10: Fabricated Machine 


\section{RESULTS}

Field trial has been carried out, considering the following parameters.

Table 2: Field Trial Details

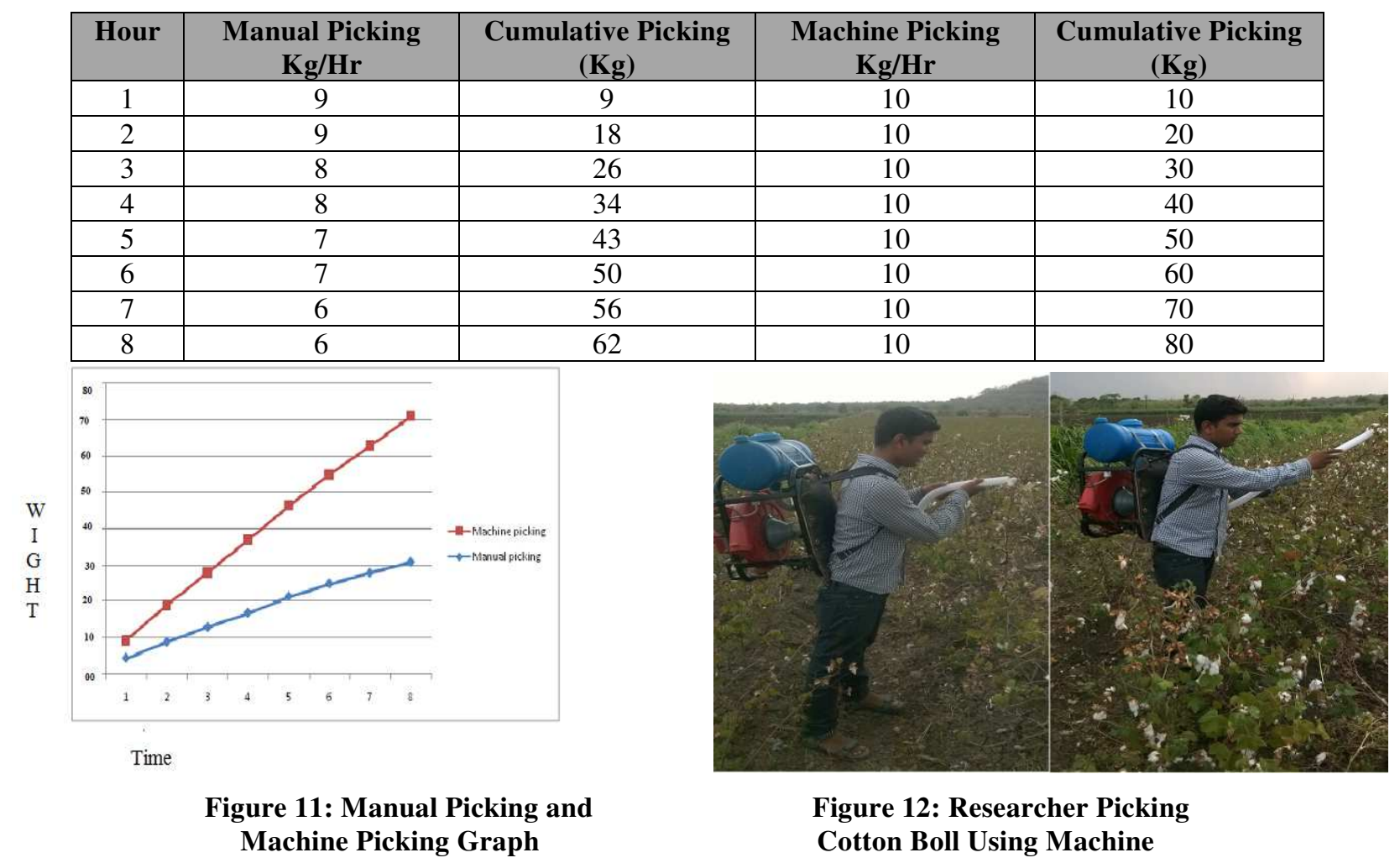

The calculated velocity and pressure values, at the outlet of impeller are found to be $66.45 \mathrm{~m} / \mathrm{s}$ and $2612.41 \mathrm{~Pa}$, and by using CFD analysis, these are $64.50 \mathrm{~m} / \mathrm{s}$ and $2413 \mathrm{~Pa}$, respectively. From figure 11, it can be concluded that, the use of proposed machine improves picking capacity of the user.

\section{REFERENCES}

1. R. Murugesan, S. K. Shukla, V. G. Arude, P. G. Patil, 'Development of Power Drive Cotton Picker', Journal of Agricultural Engineering Today, Volume 28, Issue 1\& 2, 2004, pp-54-58.

2. J Prasad, Kapur Tarun, N. S. Sandhar, G Majumdar, P. G. Patil, S. .K Shukla, B. N Jaiswal, A.B. Patil, Performance Evaluation of Spindle Type Cotton Picker', Journal of Agricultural Engineering (New Delhi), Volume 44, Issue 44, 2007, pp$38-42$.

3. M. Muthamilselvan, K. Rangasamy and A. Sampathrajan, 'Feasibility and Economic Viability of Knapsack Cotton Picker in India, Indian Journal of Agriculture and Research, Volume 144, Issue 2, 2007, pp. 86 - 91.

4. S. S. Kohli, Manjeet Singh, Karun Sharma and Gayatri Kansal, 'Multiple Attribute Decision Making for Selection of Mechanical Cotton Harvester, Scientific Research and Essays, Volume 8, Issue 48, 2013, pp-2318-2331.

5. Ankit Sharma, S. S. Ahuja, V. P. Sethi, Derminder Singh, 'Design and Development of an Experimental Cotton Picking Machine', Aid: Part I, Agricultural Mechanization in Asia, Africa, and Latin America, Volume 42 No.1, 2011, pp-28-34.

6. Nakul G. Mahalle, Dr. K. S. Zakiuudin and P. S. Kadu, 'Design and development of Pneumatic Cotton Picking Machine', International Journal of Advanced and Innovative Research, ISSN: 2278-7844, Volume 3, Issue 8, 2014, pp - 251-256. 
7. B. D. Shiwalkar, 'Design Data Book for Machine Elements', Denett \& Company Publications, $3^{\text {rd }}$ Edition, 2010, pp-112-213.

8. Dr. R. K. Bansal, 'A text book of Fluid Mechanics and Hydraulic Machines', Laxmi Publications, $9^{\text {th }}$ Edition, December 2004, pp-726-760. 